\title{
Course and Training Models Online Application Services (LAO-KURSUS) and Learning Management System (LMS) to Improve Student Competencies
}

\author{
Jamaluddin $^{1, *}$, Patta Bundu ${ }^{1}$, Anshari ${ }^{1}$, Muhammad Yunus ${ }^{2}$ \\ ${ }^{1}$ Department of Education, Makassar State University, South Sulawesi, Indonesia \\ ${ }^{2}$ Department of Education, Universitas Bosowa, South Sulawesi, Indonesia
}

Received March 31, 2021; Revised May 27, 2021; Accepted June 5, 2021

\begin{abstract}
Cite This Paper in the following Citation Styles
(a): [1] Jamaluddin, Patta Bundu, Anshari , "Course and Training Models Online Application Services (LAO-KURSUS) and Learning Management System (LMS) to Improve Student Competencies," Universal Journal of Educational Research, Vol. 9, No. 6, pp. 1258-1273, 2021. DOI: 10.13189/ujer.2021.090615.
\end{abstract}

(b): Jamaluddin, Patta Bundu, Anshari (2021). Course and Training Models Online Application Services (LAO-KURSUS) and Learning Management System (LMS) to Improve Student Competencies. Universal Journal of Educational Research, 9(6), 1258-1273. DOI: 10.13189/ujer.2021.090615.

Copyright $\bigcirc 2021$ by authors, all rights reserved. Authors agree that this article remains permanently open access under the terms of the Creative Commons Attribution License 4.0 International License

\begin{abstract}
This study aims to determine the level of validity, practicality, and effectiveness (development stage) of developing a course model and training based on online application services and a Learning Management System (LMS) to improve students' competence in the computer field. This research focuses on the development stage of the ADDIE theory (1) analysis, (2) design, (3) development, (4) implementation, and (5) evaluation) Robert Maribe Branch (2009). The development stage consists of the validity test by the expert, the practicality test by the instructor, and the effectiveness test by the students. The subjects of this study were 30 students and 7 instructors of the Computer Course Program at the Makassar City Course and Training Institute. In addition, five validators were selected as participants to assess the validity of this research product. The data collection techniques used were validation sheets, questionnaires, and tests. The collected data were analyzed using a quantitative approach with the help of SPSS 22.00. The results showed that the research products in the form of model books and course model tools and training based on online application services and Learning Management System (LMS) were declared valid, practical, and effective and could be used by instructors to teach courses and computer training.
\end{abstract}

Keywords Competence, Course and Training Models, Online Application Services, Learning Management
System, Practicality, Effectiveness

\section{Preliminary}

The law on the national education system of the Republic of Indonesia states that education is a conscious and planned effort to create an atmosphere of learning and the learning process so that students actively develop their potential to have religious-spiritual strength, self-control, personality, intelligence, noble character, and skills needed by themselves, society, nation, and state.[1]. Along with the development of the world today, especially the use of information and communication technology in the education process is starting to have a positive impact and shows significant changes, especially the use of information and communication technology in learning during the Covid-19 pandemic. One of them is the use of an online-based learning system, namely the Learning Management System (LMS), which is technology related to retrieval, collection, processing, storage, distribution, and presentation of information.[2] Using an online learning LMS will help with administration, learning schedules, and collaboration between teachers and students which as a whole takes place online using a computer device. [3]online 
application service-based courses and training models and Learning Management System (LMS) based have an important role in modern education and can improve students' skills. Currently, many students have finished their education, but are not able to work because they do not have skills. Hence this model is very beneficial for the local government because it provides skills to students, reduces unemployment, and at the same time empowers regional potentials to support the revival of the community's economy through various business skills. In addition, it can encourage students' creativity while suppressing social problems caused by non-productive activities this model has a strategic value in increasing student competence and shaping the nation's competitiveness.[4] [5]. The application of this model aims to provides insight into learning system change innovations, in particular the use of learning management systems, starting from the features and benefits of the Learning Management System (LMS) as a software application used to plan, implement, and assess certain learning processes. Typically, learning management systems provide instructors with ways to create and deliver content, monitor student participation, and assess students' performance online.[6] [7] This is what requires the writer to develop a Course model and training based on online application services and based on Learning Management System (LMS) for early childhood education teachers to support distance learning based on a learning management system (LMS).

\section{Study of Literature}

Article 26 paragraph (4) and (5) of the National Education System Law of the Republic of Indonesia states that course and training institutions as non-formal education units are organized for people who need knowledge; skills, life skills, and attitudes for self-development, professional development, work, independent business, and/or continuing education to a higher level.[8] [9]

Online Course Application Service (LAO-Course) is an Android-based application developed by the author which can be downloaded via the google play store. This application is used by students or prospective students for registration via their smartphone when they will take part in learning at course and training institutions. If students have registered, the next step is for students to order course and training services by the course programs offered by the Course and Training Institute. if the registration administration process has been completed, the learning process will be carried out online based on the Learning Management System (LMS) according to the schedule set by the course and training institution.[10] [11]

Learning Management Systems (LMS) is a web-based system that allows instructors and/or students to share material, submit and return assignments, and communicate online. [12] Learning Management System (LMS) is becoming more and more attractive these days. Modern education is highly technically dependent and this has redefined the teaching and learning process. The Learning Management System (LMS) has positive implications for education. Learning management systems are considered to be most applicable to the natural sciences that are possible.[13] The development of the internet and its applications determine the increasing role of computer-based instruments in the learning process. This is the reason why educational institutions have an increasing need to use a virtual learning environment (VLE), which is an electronic learning platform that accompanies the traditional teaching-learning-assessment process. As a result, a series of applications emerged, having the role of enabling the integral file management of the online learning process, as well as mixed-type learning applications.[14] In modern education, an important place is taken by e-learning whose development is substantially determined by the evolution of technology. Modern e-learning passes from applying separate technologies (video, multimedia, e-mail, etc.) to system decisions in which the Learning Management System (LMS) and social networking (SN) dominate. With this, the preferences of students and teachers depend on many factors - from the level of technology development in higher education institutions to the information culture features of e-learning participants.[15]

Although it cannot replace traditional education, the internet opens up new opportunities for teaching and learning assessment. The information obtained in this way, the mobility of its use, makes e-learning emerge as a complement and continuation of traditional education. Based on some of the above opinions, and the results of research on the use of applications (Learning Management System) in the teaching process in educational units, the researchers concluded that the use of the Learning Management System (LMS) application in the learning process in all educational units at various levels of education is very useful. Especially in the Course and Training education Institution.[16]

Online Application Service-Based Course and Training Model (LAO-Course) and Today's Learning Management System (LMS) can be used as an adjunct to traditional didactic activities, known as Blended Learning. Increasing the use of LMS will have an important impact on the learning process. Applications (Learning Management System) such as google classroom have been widely used in Indonesia, the LMS google classroom application is here as support for educators who aim to improve the quality of online courses, but also as a support for students to facilitate their learning.[17] [18] Syntax Online Application Service-Based Courses and Training Learning Management System (LMS) is as follows: (a) pre-learning, 
(b) presentation of material, (c) discussion; (d) assignment (e) and evaluation.[19]

\section{Materials and Methods}

\section{Research Methods}

This research is a Research and Development which refers to the ADDIE Product Development Concept according to the Branch. The ADDIE development concept consists of 5 stages, namely (1) analysis, (2) design, (3) development, (4) implementation, and (5) evaluation.[20].

The description of each stage in the ADDIE model is as follows:

\section{Analysis}

The author carried out a preliminary study at the Training and Course Institutions spread across several districts/cities in the South Sulawesi Province of the Republic of Indonesia. The author sees the implementation of course learning and training carried out conventionally and online. The implementation of this preliminary study was carried out using the method of observation, questionnaires, and unstructured interviews. The results of filling out the questionnaire are only $15 \%$ of the course and training institutions have implemented online learning and $85 \%$ still provide conventional services, both in terms of services and in the learning process. The results of observations and interviews found several problems faced by course and training institutions in the implementation of online learning, namely (1) no internet network.

\section{Design}

The author compiles the design of the Online Application Service-based Course and Training Model (LAO-Course) and the Learning Management System (LMS). Determine Competency Standards, Basic Competencies, and Material for course and training programs that are tried out according to national education standards.

\section{Development}

The author develops Programs and Guidelines for Online Application Services, Develops Learning Management System (LMS) based courses and training, Develops Organizing Guidelines for the course and training leaders, compiles guidelines for instructors, and compiles guidelines for students.

\section{Implementation}

This stage consists of:

a) Expert validation test
The expert validity test is the testing of the model produced by two material experts, two media experts, and one linguist who assesses all the products developed. [21]

\section{b) Practicality test}

The practicality test is a response by the instructor regarding the use of online application service-based training and training programs (LAO-Course) and Learning Management System (LMS) in the learning process. The next practical test is how students think about the implementation of online application service-based training and training programs (LAO-Course) and learning management system (LMS). at the practicality test stage the questionnaire was given to 7 instructors and 30 students to assess the course and training model starting at the registration process through the Android-based online application service program (LAO-Course), then the learning process based on the Learning Management System (LMS) using google classroom.

\section{Evaluation}

\section{a) Effectiveness test}

Test effectiveness is a trial process to see the effectiveness of the model. The effectiveness test uses One-Group Pretest-Posttest Design. Retrieval of data on the effectiveness of this result is measured by taking data from the pretest test results before being given treatment and posttest results after being given treatment. Thus, the treatment results can be found to be more accurate. To eliminate bias from the research results, the pretest and posttest will be carried out for two sessions of learning material. The one-group pretest-posttest design scheme is shown as follows[22] :

Table 1. One-Group Pretest-Posttest Design

\begin{tabular}{|c|c|c|}
\hline Pretest & Treatment & Post-test \\
\hline $\mathrm{T} 1 \mathrm{~T} 2$ & $\mathrm{X}$ & $\mathrm{T} 3 \mathrm{~T} 4$ \\
\hline
\end{tabular}

Description:

$\mathrm{T} 1=$ Pretest value before using the model in learning session 1

$\mathrm{T} 2=$ Pretest value before using the model in learning session 2

$\mathrm{X}=$ Treat (Treatment) given to students by using Online Application Service (LAO-Course) and Learning Management System (LMS) -based Training Model

$\mathrm{T} 3=$ Posttest value after using the model in learning session 1

$\mathrm{T} 4=$ Posttest value after using the model in learning session 2

The trial of this model was implemented in a small group of 30 respondents, the respondent's profession was a teacher of early childhood education, the gender of the 
respondent was a woman, the course program tested was a computer course program consisting of several materials, namely:

Table 2. Piloted course programs

\begin{tabular}{|l|c|}
\hline \multicolumn{1}{|c|}{ Theory } & Information \\
\hline $\begin{array}{l}\text { 1) Teacher Character Education Early childhood } \\
\text { education; }\end{array}$ & \\
2) Occupational Safety and Health Procedures; & \\
3) Law and Code of Ethics for Intellectual Property & \multirow{2}{*}{ Session 1 } \\
Rights in the Information and Communication & \\
Technology Sector; & \\
4) Microsoft Windows \& Introduction to Browsing & \\
and Web-Mail; & \\
\hline 5) Microsoft Word; & Session 2 \\
6) Microsoft Excel; & \\
7) Microsoft Powerpoint; & \\
8) Microsoft Access. & \\
\hline
\end{tabular}

\section{Research and Participant Sites}

This development process was carried out online for early childhood education teachers in the city of Makassar, South Sulawesi Province, the gender the teacher was 30 women. There were 7 instructors, consisting of 2 men and 5 women. Meanwhile, 5 experts consist of 4 men and 1 woman. Participants in this study can be divided into three groups, namely: (a) early childhood education teachers, (b) instructors, and (c) 5 experts.[23]

\section{Data Collection}

\section{Expert Validation Sheet}

This validation sheet is intended for validators to measure the level of validity of the product being developed. The validation sheet used in this study consists of the Course and Training Model Validation Sheet, the Manual Validation Sheet for Course and Training Administrators, the Manual Manual Validation Sheet for Instructors, the Manual Manual Validation Sheet for Students, the Online Application Service Guidebook Validation Sheet and instrument validation sheet for practical model and instrument test questions.

\section{Questionnaire Instructor Response}

In testing the level of practicality, researchers need to use an instructor response questionnaire to provide justification and assessment of the online application service-based course and training model (LAO-Course) and the Learning Management System (LMS). This instructor response questionnaire consists of four aspects which include: (1) Clarity of Instructions for Using the Learning Implementation Plan, (2) Achievement of Competencies and Learning Objectives, (3) Student Response, (4) Difficulty level in implementing. And (5) Adequacy of Time. This questionnaire consists of 16 statements in the form of a Likert scale with the highest score of 4 and the lowest score of 1 .

\section{Questionnaire Student Responses}

Another instrument used to measure the practicality of the online application service-based course and training model (LAO-Course) and the Learning Management System (LMS) is a student response questionnaire. This questionnaire consists of ten aspects of assessment, namely: (1)Attract students' attention, (2) Giving motivation, (3) Clarity of Material, (4) Use of the right examples (5) Class management skills, (6) Using time effectively, (7) emphasizing character values and (10) drawing conclusions. This questionnaire consists of 10 statements in the form of a Likert scale with the highest score of 4 and the lowest score of 1 .

\section{Learning Outcomes Test}

Give learning outcomes tests by the indicators and objectives developed by the researcher. The test is used to measure or determine the contribution of developing a course model and training based on online application services (LAO-Course) and a Learning Management System (LMS) to see the improvement in students' abilities through courses and training in computer office applications. Tests conducted before being referred to students have been tested for validation first. The test consists of four sessions used before (pretest) and after (posttest) treatment that measures students' ability to the course material and training provided, namely: 1)Teacher Character Education Early childhood education, 2) Occupational Safety and Health Procedures, 3) Law and Code of Ethics for Intellectual Property Rights in the Information and Communication Technology Sector. 4) Microsoft Windows \& Introduction to Browsing and Web-Mail. 5) Microsoft Word, 6) Microsoft Excel, 7) Microsoft Powerpoint, 8) Microsoft Access.

\section{Data Analysis}

\section{Data analysis for the level of validity}

Data analysis techniques for validation of course and training model validation sheets, manual validation sheets for the course and training providers, manual validation sheets for instructors, manual validation sheets for students, manual book validation sheets for online application services courses, and training and instrument validation sheets practicality of the models and instruments of the exam questions. The data obtained were analyzed using the average score for each aspect and then the overall average score was calculated using the following formula:

$$
\mathrm{P}=\mathrm{x} 100 \% \frac{\sum x}{\sum x i}[24]
$$

Information :

$\mathrm{P}=$ Percentage of validity 
$\sum x=$ The total number of answers in all items

$\sum x i=$ The total number of ideal scores in all items

$100=$ Constant

Table 3. Assessment Guidelines for data analysis for the level of expert validity using a Likert scale

\begin{tabular}{ccc}
\hline No. & Score & Information \\
\hline 1 & Score 5 & Very agree / very worthy \\
\hline 2 & Score 4 & Agree / comply \\
\hline 3 & Score 3 & Hesitating / sometimes / quite \\
\hline 4 & Score 2 & Disagree / not well \\
\hline 5 & Score 1 & Very disagree / very unfavorable \\
\hline
\end{tabular}

The criteria used for the analysis of the level of achievement and quality of the feasibility of the model are presented in the following table:

Table 4. Category of validity assessment by expert the Online Application Service-based Course and Training Model (LAO-Course) and the Learning Management System (LMS)

\begin{tabular}{cc}
\hline Rating category & Score Interval \\
\hline Very Invalid: & $0 \leq \overline{\boldsymbol{x}} \leq 1$ \\
Invalid: & $1 \leq \overline{\boldsymbol{x}} \leq 2$ \\
\hline Enough Valid: & $2 \leq \overline{\boldsymbol{x}} \leq 3$ \\
\hline Valid: & $3 \leq \overline{\boldsymbol{x}} \leq 4$ \\
Very Valid: & $4 \leq \overline{\boldsymbol{x}} \leq 5$ \\
\hline
\end{tabular}

\section{Data analysis for the level of practicality}

The data from the instructor and student response questionnaires were analyzed separately by determining the average score of responses than matched with a predetermined score interval table using the following formula:

Table 5. Practicality level assessment categories by instructors and students in the Online Application Service-based Course and Training Model (LAO-Course) and the Learning Management System (LMS)

\begin{tabular}{ccc}
\hline Number & Score & Information \\
\hline 1 & Score 4 & very good \\
\hline 2 & Score 3 & good \\
\hline 3 & Score 2 & Not good \\
\hline 4 & Score 1 & Very less \\
\hline
\end{tabular}

\section{Data analysis for effectiveness}

The technical analysis of increasing the competence of students is carried out quantitatively Analysis of student learning outcomes measures the effectiveness of course learning outcomes and office application computer training. Calculations were performed using Microsoft Excel and SPSS 22.00. The ability of students' learning outcomes of all course material after being given treatment using the course model and training was carried out inferential statistical analysis with SPSS 22.00.

\section{Result}

As previously explained, this study aims to investigate the development stage of research and development using the ADDIE theory. This development stage consists of three main parts, namely: (1) validation test, (2) practicality test, and (3) effectiveness test. This means that the products developed in the form of training models based on online application services (LAO-Courses) and learning management systems (LMS) have been designed and continued for trials at the development stage. The test results in the three sections can be seen in the following description.

The validity of the product being developed

\section{Expert Validation of Course Model Materials and Training Based on online application services (LAO-Courses) and learning management systems (LMS)}

Obtained the average value of each aspect of the assessment in the model book can be seen in the following table:

Table 6. Average of Material Expert Validation Results to the Model Courses and Training Based on online application services (LAO-Courses) and learning management systems (LMS)

\begin{tabular}{ccccc}
\hline Number & $\begin{array}{c}\text { Assessment } \\
\text { Aspects }\end{array}$ & (Ai) & $\bar{x}$ & Ket \\
\hline 1 & $\begin{array}{c}\text { Model Book } \\
\text { Components: }\end{array}$ & 4,2 & 4.09 & $\begin{array}{c}\text { Very } \\
\text { Valid }\end{array}$ \\
\hline 2 & Curriculum & 4,1 & 4.09 & $\begin{array}{c}\text { Very } \\
\text { Valid }\end{array}$ \\
\hline 3 & $\begin{array}{c}\text { Material } \\
\text { Content: }\end{array}$ & 4,2 & 4.09 & $\begin{array}{c}\text { Very } \\
\text { Valid }\end{array}$ \\
\hline 4 & Learning: & 4,3 & 4.09 & $\begin{array}{c}\text { Very } \\
\text { Valid }\end{array}$ \\
\hline 5 & $\begin{array}{c}\text { Interaction and } \\
\text { Feedback: }\end{array}$ & 3,7 & 4.09 & Valid \\
\hline \multicolumn{5}{c}{ Total Value } \\
Average
\end{tabular}

For the total average value of the validity of the model according to material expert validation for all aspects of the assessment obtained $=4.09$ based on the validity criteria mentioned above, this value is included in the Very Valid category, which is at $4 \leq \overline{\boldsymbol{x} \boldsymbol{x}} \leq 5$. When viewed from all aspects of this format, then the Online Application Service-based Course and Training Model (LAO-Course) and the Learning Management System (LMS) are declared to meet the validity criteria.

\section{Media Expert Validation Online Application Services (LAO-Course) and Learning Management System (LMS) -based Training Model.}

The average score for each aspect of the media assessment can be seen in the following table: 
Table 7. Average Validation Results of Media Experts on the Model Online Application Services (LAO-Course) and Learning Management System (LMS) -based Courses and Training

\begin{tabular}{cccccc}
\hline No. & Assessment Aspects & $(\mathrm{Ai})$ & $\bar{x}$ & Ket \\
\hline 1 & Graphic Feasibility Components & 3.8 & 3.65 & Valid \\
\hline 2 & Book Cover Design & 3,4 & 3.65 & Valid \\
\hline 3 & Book Cover Typography - The fonts used are attractive and easy to read & 3,9 & 3.65 & Valid \\
\hline 4 & Book Cover Illustration - Reflects the contents of the book & 3,3 & 3.65 & Valid \\
\hline 5 & Book Contents Design - Book Contents Layout & 3,6 & 3.65 & Valid \\
\hline 6 & Book Content Design - Typography of Book Contents & 3,9 & 3.65 & Valid \\
\hline & Total Value & 21.9 & & & \\
\hline & Average & 3.65 & & \multicolumn{2}{c}{ Valid }
\end{tabular}

For the total average value of validity according to the validation of media experts for all aspects of the assessment obtained $=3.65$ based on the validity criteria mentioned above, this value is included in the Valid category, which is at $3 \leq \overline{\boldsymbol{x}} \leq 4$. If viewed from all aspects of this format, then The Online Application Service (LAO-Course) and Learning Management System (LMS) -based Course and Training Model are declared to meet the validity criteria.

\section{Media Expert Validation}

Assessment of media expert validation of the google classroom application on the Based Course and Training ModelOnline Application Services (LAO-Course) and Learning Management System (LMS) Obtained the average value of each aspect of media assessment in this application can be seen in the following table:

Table 8. Average Media Expert Validation Results on the Google Classroom LMS Application

\begin{tabular}{|c|c|c|c|c|}
\hline Number & $\begin{array}{c}\text { Assessment } \\
\text { Aspects }\end{array}$ & (Ai) & $\bar{x}$ & Ket \\
\hline 1 & $\begin{array}{c}\text { Application } \\
\text { Eligibility } \\
\text { Component }\end{array}$ & 3,7 & 3.85 & Valid \\
\hline 2 & $\begin{array}{c}\text { Software } \\
\text { Engineering } \\
\text { Aspects } \\
\end{array}$ & 3,9 & 3.85 & Valid \\
\hline 3 & $\begin{array}{c}\text { Visual } \\
\text { Communication } \\
\text { Aspects } \\
\end{array}$ & 3,9 & 3.85 & Valid \\
\hline 4 & $\begin{array}{c}\text { LMS } \\
\text { Application } \\
\text { Aspect - Google } \\
\text { Classroom } \\
\end{array}$ & 3,9 & 3.85 & Valid \\
\hline & Total Value & 15.4 & & \\
\hline & Average & 3.85 & & Valid \\
\hline
\end{tabular}

For the total average value of the validity of the LMS Google Classroom application according to media expert validation for all aspects of the assessment obtained = 3.85 based on the validity criteria mentioned above, this value is included in the Valid category, which is at $3 \leq$ $\overline{\boldsymbol{x}} \boldsymbol{x} \leq 4$. If viewed from all aspects of this format, then the Google Classroom Application is declared to meet the validity criteria.

\section{Material Expert Validation in the Manual of Course and Training Institutions Management}

The material expert validation assessment of the Course and Training Institution Management Handbook obtained the average value of each aspect in the following table:

Table 9. Average Results of Material Expert Validation in the Manual of Course and Training Institutions Management

\begin{tabular}{|c|c|c|c|c|}
\hline Number & $\begin{array}{l}\text { Assessment } \\
\text { Aspects }\end{array}$ & (Ai) & $\bar{x}$ & Ket \\
\hline 1 & Management & 4.00 & 4.03 & Very Valid \\
\hline 2 & $\begin{array}{l}\text { Use of LMS } \\
\text { Applications in } \\
\text { Courses and } \\
\text { Training }\end{array}$ & 4.13 & 4.03 & Very Valid \\
\hline 3 & $\begin{array}{c}\text { Interface (LMS } \\
\text { Application } \\
\text { Display) } \\
\end{array}$ & 4.00 & 4.03 & Very Valid \\
\hline \multirow[t]{3}{*}{4} & $\begin{array}{c}\text { Graphic Design } \\
\text { and Audio } \\
\text { Visual } \\
\end{array}$ & 4.00 & 4.03 & Very Valid \\
\hline & Total Value & 16.13 & & \\
\hline & Average & 4.03 & & Very Valid \\
\hline
\end{tabular}

For the total average value of the validity of the Guidebook for the Management of the Course and Training Institute for all aspects of the assessment obtained $=4.03$ based on the validity criteria mentioned above, this value is included in the Very Valid category, which is at $4 \leq \overline{\boldsymbol{x}} \boldsymbol{x} \leq 5$. When viewed from all aspects to this format, the Guidebook for the Management of the Course and Training Institution is declared to meet the validity criteria.

\section{Material Expert Validation in the Instructor's Manual}

The material expert validation assessment of the Instructor's Guide, the average score for each aspect is obtained in the following table: 
Table 10. Average of Material Expert Validation Results in the Instructor's Manual

\begin{tabular}{ccccc}
\hline No. & $\begin{array}{c}\text { Assessment } \\
\text { Aspects }\end{array}$ & (Ai) & $\bar{x}$ & Ket \\
\hline 1 & $\begin{array}{c}\text { LMS Based } \\
\text { Learning }\end{array}$ & 4.00 & 4.00 & Very Valid \\
\hline $\begin{array}{c}\text { Use of LMS } \\
\text { Applications in } \\
\text { Courses and } \\
\text { Training }\end{array}$ & 4.00 & 4.00 & Very Valid \\
\hline $\begin{array}{c}\text { LMS } \\
\text { Application } \\
\text { Display }\end{array}$ & 4.00 & 4.00 & Very Valid \\
\hline $\begin{array}{c}\text { Graphic Design } \\
\text { and Audio } \\
\text { Visual }\end{array}$ & 4.00 & 4.00 & Very Valid \\
\hline Total Value & 16.00 & Very \\
\hline Average & 4.00 & Valid \\
\hline
\end{tabular}

For the total average value of the validity of the Instructor Manual according to the material expert validator for all aspects of the assessment obtained $=4.00$ based on the validity criteria mentioned above, this value is included in the Very Valid category, which is at $4 \leq$ $\overline{\boldsymbol{x}} \boldsymbol{x} \leq 5$. When viewed from all aspects of this format, the Instructor Manual is declared to meet the validity criteria.

\section{Material Expert Validation in the Student Manual}

The material expert validation assessment of the Student Manual obtained the average value of each aspect in the following table:

Table 11. Average Results of Material Expert Validation in Student Handbooks

\begin{tabular}{ccccc}
\hline No. & Assessment Aspects & $(\mathrm{Ai})$ & $\bar{x}$ & Ket \\
\hline 1 & $\begin{array}{c}\text { Use of a Learning Management } \\
\text { System (LMS) Based Model } \\
\text { Application }\end{array}$ & 3.25 & 3.48 & Valid \\
\hline 2 & $\begin{array}{c}\text { Interface / Display Learning } \\
\text { Management System (LMS) } \\
\text { Application and Facilities }\end{array}$ & 3.70 & 3.48 & Valid \\
\hline Total Value & 6.95 & \\
\hline Average & 3.48 & Valid \\
\hline
\end{tabular}

For the total average value of the validity of the Student Manual according to the material expert validator for all aspects of the assessment obtained $=3.48$ based on the validity criteria mentioned above, this value is included in the Valid category, which is at $3 \leq \overline{\boldsymbol{x}} \boldsymbol{x} \leq 4$. If viewed from all aspects of the format, the Student Manual is declared to meet the validity criteria.

\section{Linguist validation on all model products}

The linguist validation assessment of all products obtained the average value for each aspect in the following table:
Table 12. Average Linguist Validation Results in Model Books, Curriculum, and Manuals

\begin{tabular}{cccc}
\hline No. & Assessment Aspects & (Ai) & Ket \\
\hline 1 & Language in Model Books & 4.90 & $\begin{array}{c}\text { Very } \\
\text { Valid }\end{array}$ \\
\hline 2 & $\begin{array}{c}\text { Language in the Model } \\
\text { Curriculum }\end{array}$ & 4.90 & $\begin{array}{c}\text { Very } \\
\text { Valid }\end{array}$ \\
\hline 3 & $\begin{array}{c}\text { Language in the Guidebook for } \\
\text { LKP Managers }\end{array}$ & 4.95 & $\begin{array}{c}\text { Very } \\
\text { Valid }\end{array}$ \\
\hline 4 & $\begin{array}{c}\text { Languages of the Instructor's } \\
\text { Manual }\end{array}$ & 4.95 & $\begin{array}{c}\text { Very } \\
\text { Valid }\end{array}$ \\
\hline 5 & $\begin{array}{c}\text { Language in the Student's } \\
\text { Manual }\end{array}$ & 5.0 & $\begin{array}{c}\text { Very } \\
\text { Valid }\end{array}$ \\
\hline \multicolumn{2}{c}{ Total Value } & 24.70 & \\
\hline & Average & 4.94 & $\begin{array}{c}\text { Very } \\
\text { Valid }\end{array}$ \\
\hline
\end{tabular}

For the total average value of validity for the language aspects of the Model Book, Curriculum, and Manual, all aspects of the assessment were obtained $=4.94$ based on the validity criteria mentioned above, this value is included in the Very Valid category, which is at $4 \leq \overline{\boldsymbol{x}} \boldsymbol{x} \leq$ 5. If reviewed from all aspects of this format, the language aspects in the Model Book, Curriculum, and Handbook are declared to meet the validity criteria.

Expert validation of the model practicality questionnaire for students

The expert validation assessment of the model practicality questionnaire instrument for students obtained the average value of each aspect in the following table:

Table 13. Average Expert Validation Results on Model Practicality Instruments for Students

\begin{tabular}{ccccc}
\hline No. & Assessment Aspects & (Ai) & $\bar{x}$ & Ket \\
\hline 1 & Aspect Instructions & 3.8 & 3.47 & Valid \\
\hline 2 & Coverage Aspects & 3,4 & 3.47 & Valid \\
\hline 3 & Aspects of Language & 3,3 & 3.47 & Valid \\
\hline & Total Value & 10.40 & & \\
\hline Average & 3.47 & & Valid \\
\hline
\end{tabular}

For the total average value of validity for the model practicality instrument for students, all aspects of the assessment were obtained $=3.47$ based on the validity criteria mentioned above, this value is included in the Valid category, which is at $3 \leq \overline{\boldsymbol{x}} \boldsymbol{x} \leq 4$. When viewed from all aspects of this format, then the model practicality instrument for students was declared to meet the validity criteria.

\section{Expert validation of the model practicality questionnaire for instructors}

The expert validator's assessment of the model practicality questionnaire instrument for the instructor obtained the average value of each aspect in the following table: 
Table 14. Average Expert Validation Results on Model Practicality Instruments for Instructors

\begin{tabular}{ccccc}
\hline No. & Assessment Aspects & $(\mathrm{Ai})$ & $\bar{x}$ & Ket \\
\hline 1 & Aspect Instructions & 3.5 & 3.20 & Valid \\
\hline 2 & Coverage Aspects & 3,1 & 3.20 & Valid \\
\hline 3 & Aspects of Language & 3.0 & 3.20 & Valid \\
\hline Total Value & 9.60 & & \\
\hline Average & & 3.20 & Valid \\
\hline
\end{tabular}

For the total average value of validity for the practicality instrument model, all aspects of the assessment were obtained $=3.20$ based on the validity criteria mentioned above, this value is included in the Valid category, which is at $3 \leq \overline{\boldsymbol{x}} \boldsymbol{x} \leq 4$. If viewed from all aspects of this format, then the model practicality instrument for students was declared to meet the validity criteria.

\section{Expert validation of model effectiveness instruments (test learning outcomes)}

The expert validation assessment of the model effectiveness instrument (learning outcome test) obtained the average value of each aspect in the following table:
Table 15. Average Expert Validation Results on Model Effectiveness Instruments (Learning Outcomes Test)

\begin{tabular}{ccccc}
\hline No. & Assessment Aspects & $(\mathrm{Ai})$ & $\bar{x}$ & Ket \\
\hline 1 & $\begin{array}{c}\text { Conformity Assessment } \\
\text { Technique }\end{array}$ & 3.0 & 3.16 & Valid \\
\hline 2 & Instrument Completeness & 3,3 & 3.16 & Valid \\
\hline 3 & Content suitability & 3.0 & 3.16 & Valid \\
\hline 4 & Problem Construction & 3,4 & 3.16 & Valid \\
\hline 5 & Language & 3,2 & 3.16 & Valid \\
\hline \multicolumn{4}{c}{ Total Value } & 15.79 \\
& Average & 3.16 & & Valid \\
\hline
\end{tabular}

For the total average value of validity for the practicality instrument model, all aspects of the assessment were obtained $=3.16$ based on the validity criteria mentioned above, this value is included in the Valid (V) category, which is at $3 \leq \overline{\boldsymbol{x}} \boldsymbol{x} \leq 4$. When viewed from all aspects of this format, then the model practicality instrument for the instructor is declared to meet the validity criteria.

\section{Practicality Test Results}

\section{Student response questionnaire}

Table 16. The average students' practicality questionnaire assessment results

\begin{tabular}{|c|c|c|c|c|c|c|c|c|c|c|}
\hline & M1 & M2 & M3 & M4 & M5 & M6 & M7 & M8 & M9 & M10 \\
\hline $\begin{array}{c}\text { Strongly } \\
\text { agree }\end{array}$ & 52.08 & 62.92 & 49.17 & 54.17 & 60.00 & 51.67 & 52.08 & 57.08 & 58.75 & 50.42 \\
\hline Agree & 45.42 & 34.58 & 45.83 & 42.50 & 37.92 & 44.17 & 43.33 & 40.42 & 39.58 & 45.42 \\
\hline $\begin{array}{c}\text { Less } \\
\text { disagree }\end{array}$ & 2.08 & 2.50 & 4.58 & 2.08 & 1.67 & 4.17 & 4.58 & 2.50 & 1.67 & 3.33 \\
\hline Disagree & 0.42 & - & 0.42 & 1.25 & 0.42 & - & - & - & - & 0.83 \\
\hline
\end{tabular}

Table 17. Information on Practicality Questionnaire Assessment by Students

\begin{tabular}{cc}
\hline M1 & At the beginning of the learning activity, the Instructor's explanation attracts students' attention \\
\hline M2 & Students are motivated to know more about the material being taught \\
\hline M3 & The material presented is clearly understood by students \\
\hline M4 & After the instructor gives an example, the students understand better the material \\
\hline M5 & Instructors often assist students if they have difficulty learning \\
\hline M6 & The time given to answer the questions is sufficient \\
\hline M7 & Students want to make a summary of the material to make it easier to understand it \\
\hline M8 & At the time of learning, students try hard to master the material well \\
\hline M9 & At the end of the lesson, the instructor guides students to conclude the learning material \\
\hline
\end{tabular}


Based on the results of filling out the students' response questionnaire on the initial aspects of learning activities, the instructor's explanation attracted students' attention, the average data obtained was $52.08 \%$ of students said Strongly Agree, $45.42 \%$ of students said Agree, $2.08 \%$ of students said Less disagree and $0,42 \%$ of students said Disagree.

Based on the results of filling out the students' response questionnaire on student aspects motivated to find out more about the material, the average data obtained was $62.92 \%$ of students said Strongly Agree, $34.58 \%$ of students said Agree, $2.50 \%$ of students said Less disagree and $0 \%$ of students said Disagree.

Based on the results of filling out the students' response questionnaire on aspects. The material presented was clearly understood by students, it was obtained that the average data was $49.17 \%$ of students said Strongly Agree, $45.83 \%$ of students said Agree, $4.58 \%$ of students said they Less disagree and $0.42 \%$ of students said they Disagree

Based on the results of filling out the students' response questionnaire on the aspects after the instructor gave an example, students became more aware of the material, the average data obtained was $54.17 \%$ of students said Strongly Agree, $42.50 \%$ of students said Agree, $2.08 \%$ of students said Less disagree and 1, 25\% of students said Disagree.

Based on the results of filling out the students' response questionnaire on the aspect of the instructor often assisting to students if they experience difficulties in learning, the average data obtained is $60.00 \%$ of students say Strongly Agree, $37.92 \%$ of students say Agree, $1.67 \%$ of students say Less disagree and 0, $42 \%$ of students said Disagree.
Based on the results of filling out the students' response questionnaire on the aspect of time given to answer the questions is sufficient, the average data obtained is $51.67 \%$ of students say Strongly Agree, $44.17 \%$ of students say Agree, $4.17 \%$ of students say Less disagree and $0 \%$ of students said Disagree.

Based on the results of filling out the response questionnaire on the aspects students want to make a summary of the material to make it easier to understand it, the average data obtained is $52.08 \%$ of students say Strongly Agree, $43.33 \%$ of students say Agree, $4.58 \%$ of students say Less disagree and $0 \%$ of students say Disagree.

Based on the results of filling out the students' response questionnaire on aspects After this study, students wanted to know more about the material being taught, the average data obtained was $57.08 \%$ of students said Strongly Agree, $40.42 \%$ of students said Agree, $2.50 \%$ of students said they Less disagree and $0 \%$ of students said Disagree.

Based on the results of filling out the student response questionnaire during learning, students tried hard to master the material well, the average data obtained was $58.75 \%$ of students said Strongly Agree, $39.58 \%$ of students said Agree, $1.67 \%$ of students said Less disagree and $0 \%$ of students said Disagree.

Based on the results of filling out the students' response questionnaire at the end of the lesson the instructor guided the students to conclude the learning material, it was found that an average of $50.42 \%$ of students said they strongly agreed, $45.42 \%$ of students said they agreed, $3.33 \%$ of students said they Less disagree and $0,83 \%$ of students said they disagreed. 
Instructor response questionnaire

Table 18. The average result of the instructor's practicality questionnaire

\begin{tabular}{|c|c|c|c|c|c|c|c|c|c|c|c|c|c|c|c|c|}
\hline & P1 & P2 & P3 & P4 & P5 & P6 & P7 & P8 & P9 & $\mathrm{P} 10$ & P11 & $\mathrm{P} 12$ & $\mathrm{P} 13$ & P14 & P15 & $\mathrm{P} 16$ \\
\hline Very less & 0 & 0 & 0 & 0 & 0 & 0 & 0 & 0 & 0 & 0 & 0 & 0 & 0 & 0 & 0 & 0 \\
\hline Less & 0 & 0 & 0 & 0 & 0 & 0 & 14.3 & 0 & 0 & 0 & 0 & 0 & 0 & 0 & 14.3 & 14.3 \\
\hline Good & 28.6 & 14.3 & 42.9 & 0 & 42.9 & 42.9 & 14.3 & 14.3 & 42.9 & 42.9 & 42.9 & 42.9 & 28.6 & 28.6 & 57.1 & 57.1 \\
\hline Very good & 71.4 & 85.7 & 57.1 & 100 & 57.1 & 57.1 & 71.4 & 85.7 & 57.1 & 57.1 & 57.1 & 57.1 & 71.4 & 71.4 & 28.6 & 28.6 \\
\hline
\end{tabular}

Table 19. Information on Practicality Questionnaire Assessment by the Instructor

\begin{tabular}{cc}
\hline P1 & The formulation of learning objectives and indicators is clearly stated \\
\hline P2 & The steps in the lesson plan are clearly stated \\
\hline P3 & The assessment instructions are clearly stated \\
\hline P4 & Time allocation is clearly stated \\
\hline P5 & The use of this model supports the maximum achievement of subject competencies \\
\hline P6 & The use of this model can foster a creative character \\
\hline P7 & The use of this model can get used to hard work \\
\hline P8 & The use of this model can encourage curiosity \\
\hline P9 & Students seem enthusiastic about the learning process \\
\hline P10 & Students show high motivation during the learning process \\
\hline P11 & Students look happy during the learning process using this model \\
\hline P12 & The stages in applying the model are easy to implement \\
\hline P13 & All learning tools are easy to use \\
\hline P14 & The learning outcome evaluation tool is easy to use \\
\hline P15 & The time used to implement this learning model is sufficient \\
\hline P16 & The time allocated is sufficient to achieve learning objectives \\
\hline
\end{tabular}


Based on the results of filling out the instructor's response questionnaire, it was found that $71.4 \%$ of the instructors said they strongly agreed that the formulation of learning objectives and indicators was clearly stated. And $28.6 \%$ of instructors said to agree that the formulation of objectives and learning indicators were clearly stated.

Based on the results of filling out the instructor response questionnaire, data were obtained that $85.7 \%$ of instructors said they strongly agreed that the steps in the lesson plan were clearly stated. And $14.3 \%$ of instructors said to agree agreed that the steps in the lesson plan were clearly stated.

Based on the results of filling out the instructor response questionnaire, data obtained that $75.1 \%$ of instructors said they strongly agreed that the assessment instructions were clearly stated. And $42.9 \%$ of instructors said to agree clearly stated assessment instructions.

Based on the results of filling out the instructor response questionnaire, it was found that $100 \%$ of the instructors said they strongly agreed that the time allocation was clearly stated.

Based on the results of filling out the instructor response questionnaire, data obtained by $75.1 \%$ of instructors said that they strongly agreed that the use of this model supports the maximum achievement of subject competencies. And $42.9 \%$ of instructors said that they agreed to use this model to support the maximum achievement of subject competencies.

Based on the results of filling out the instructor response questionnaire, data obtained that $75.1 \%$ of instructors said they strongly agreed that the use of this model could foster creative character. And $42.9 \%$ of instructors said agree that the use of this model can foster creative character.

Based on the results of filling out the instructor response questionnaire, it was found that $71.4 \%$ of instructors said they strongly agreed that the use of this model could get used to working. $14.3 \%$ of instructors said to agree that the use of this model can get used to working. And $14.3 \%$ of instructors said that they didn't agree that the use of this model could get used to working.

Based on the results of filling out the instructors' response questionnaire, it was found that $85.7 \%$ of the instructors said they strongly agreed that the use of this model could encourage curiosity. And $14.3 \%$ of instructors said Agree using this model can encourage curiosity.

Based on the results of filling out the instructor's response questionnaire, it was found that $57.1 \%$ of the instructors said they strongly agreed that students seemed enthusiastic about the learning process. And $42.9 \%$ of instructors said to agree that students looked enthusiastic about the learning process.

Based on the results of filling out the instructor response questionnaire, it was found that $57.1 \%$ of the instructors said they strongly agreed that students showed high motivation during the learning process. And $42.9 \%$ of instructors said agree that students showed high motivation during the learning process.

Based on the results of filling out the instructor response questionnaire, it was found that $57.1 \%$ of the instructors said they strongly agreed that students looked happy during the learning process using this model. And $42.9 \%$ of instructors said agree that students look happy during the learning process using this model.

Based on the results of filling out the instructor's response questionnaire, it was found that $57.1 \%$ of the instructors said they strongly agreed that the stages in implementing the model were easy to implement. And $42.9 \%$ of instructors said Agree, the stages in the application of the model are easy to implement.

Based on the results of filling out the instructor response questionnaire, data obtained $71.4 \%$ of instructors said they strongly agree that all learning tools are easy to use. And 26.6\% of instructors said Agree all learning tools are easy to use.

Based on the results of filling out the instructor response questionnaire, it was found that $71.4 \%$ of the instructors said they strongly agreed that all learning outcome evaluation tools were easy to use. And 26.6\% of instructors said they Agree all learning outcome evaluation tools are easy to use.

Based on the results of filling out the instructor response questionnaire, data obtained $26.6 \%$ of instructors said that they strongly agreed that the time used to implement this learning model was sufficient. $57.1 \%$ of instructors said that they agreed that the time spent implementing this learning model was sufficient. And $14.3 \%$ of instructors said that the time spent to implement this learning model was insufficient.

Based on the results of filling out the instructor response questionnaire, data were obtained that $26.6 \%$ of instructors said that they strongly agreed that the time allocated was sufficient to achieve learning objectives. $57.1 \%$ of instructors said that agreed that the time allocated was sufficient to achieve the learning objectives. And $14.3 \%$ of instructors said that they less agree with the time allocated to achieve learning goals.

\section{Effectiveness test results}

Before further testing is carried out, the students' pretest and posttest data are tested to see whether the data is normal or not, the data is called normally distributed if it meets the normality criteria, namely if Sig. > A (0.05) and not normally distributed if Sig. $<\mathrm{A}(0.05)$. Table 24 is the result of processing with the help of SPSS in testing the normality of the pretest and posttest data.

Based on table 24, shows that the results of the normality test in the pretest and posttest session 1 obtained the Sig. $=0.083>0.05$, then Based on table 25 
shows that the results of the normality test in the pretest and posttest session 2 obtained the value of Sig Sig. = $0.130>0.05$. This shows that the pretest and posttest data meet the normality test criteria so that it can be concluded that the results of students' ability tests through computer learning office applications for early childhood education teachers in Makassar City are normally distributed.

\section{Session Effectiveness Test 1}

The results of the pretest and posttest session 1 were analyzed using the SPSS application descriptively; the following data in table 22 were obtained.

Research Hypothesis:

Ho: There is no average difference between the Pre-study outcomes test and Post-test, which means that there is no effect of the course model and training based on Online Course Application Services (LAO-Course) and
Learning Management System (LMS) in improving learning outcomes.

Ha: There is a difference in the average between the pretest and posttest learning outcomes, which means there is no influence of the course model and training based on Online Course Application Services (LAO-Course) and the Learning Management System (LMS) in improving learning outcomes.

The basis for decision making in the Paired Sample T-Test, namely:

If the significance value (2-tailed) $<0.05$ then Ho is rejected and Ha is accepted.

If the significance value (2-tailed) $>0.05$ then Ho is accepted and Ha is rejected.

After the Paired Sample T-Test was carried out using SPSS for course learning and training session 1, the following data in table 23 were obtained.

Table 20. The results of the normality test pre-test and post-test session 1 Paired Samples Correlations

\begin{tabular}{ccccc}
\hline & & N & Correlation & Sig. \\
\hline Pair 1 & Pre_Test_Session_1 \& Post_Test_Session_1 & 30 &, 321 &, 083 \\
\hline
\end{tabular}

Table 21. The results of the normality test pre-test and post-test session 2

\begin{tabular}{ccccc}
\hline \multicolumn{5}{c}{ Paired Samples Correlations } \\
\hline Pair 1 & Pre-Test Session 2 \& Post Test Session 2 & N & Correlation & Sig. \\
\hline
\end{tabular}

Table 22. Descriptive Statistics of Pretest and Posttest Session Results 1

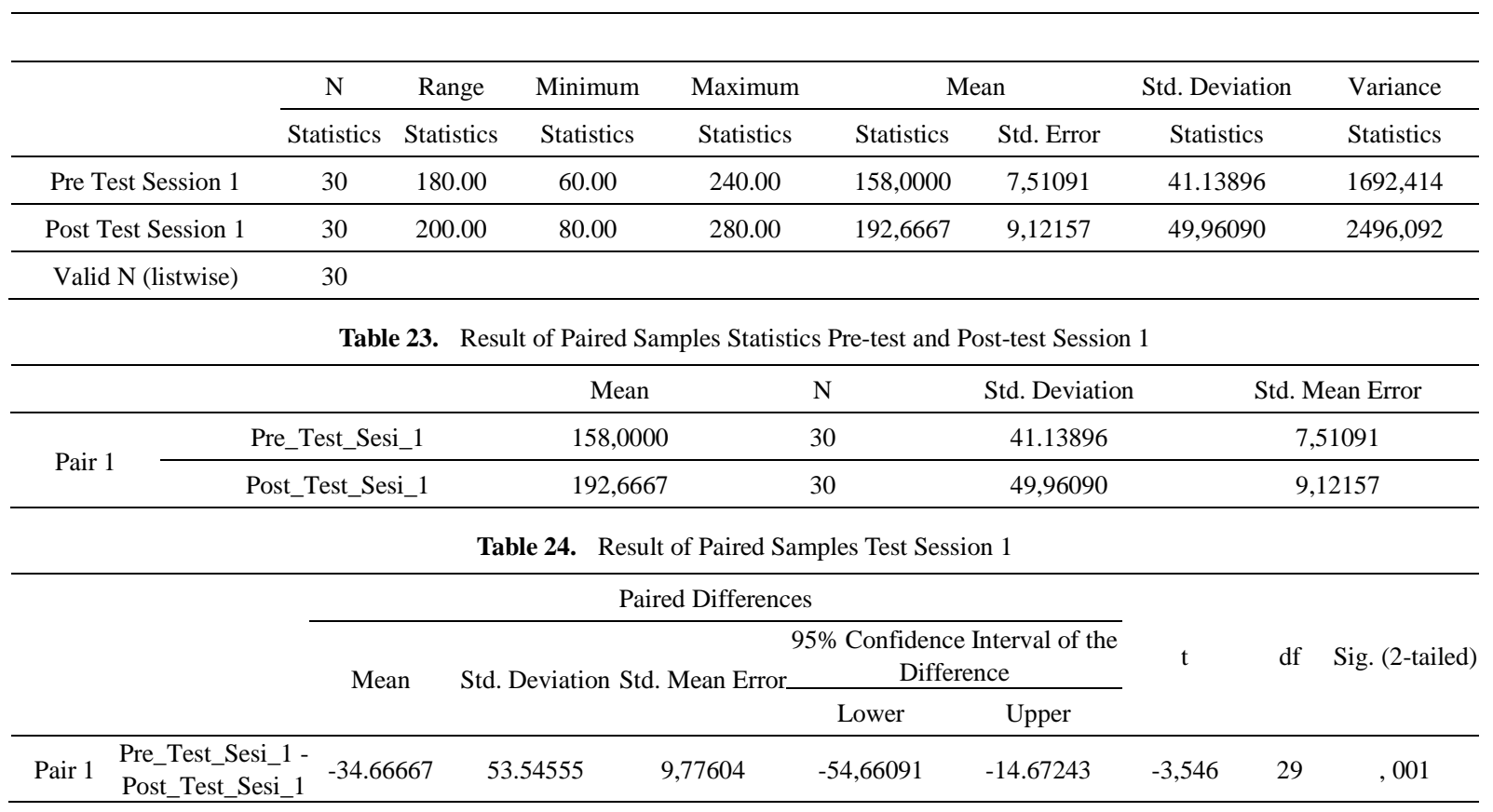


Table 25. Descriptive Statistics of Pre-test and Post-test Session Results 2

\begin{tabular}{ccccccccc}
\hline & $\mathrm{N}$ & Range & Minimum & Maximum & \multicolumn{2}{c}{ Mean } & Std. Deviation & Variance \\
\cline { 2 - 9 } & Statistics & Statistics & Statistics & Statistics & Statistics & Std. Error & Statistics & Statistics \\
\hline Pre Test Session 2 & 30 & 300.00 & 100.00 & 400.00 & 220,6667 & 13,50975 & 73.99596 & 5475,402 \\
\hline Post Test Session 2 & 30 & 260.00 & 140.00 & 400.00 & 302,0000 & 12,87785 & 70,53490 & 4975,172 \\
\hline Valid N (listwise) & 30 & & & & & & & \\
\hline
\end{tabular}

Table 26. Result of Paired Samples Statistics Pre-test and Post-Test Session 2

\begin{tabular}{cccccc}
\hline & & Mean & N & Std. Deviation & Std. Mean Error \\
\hline \multirow{2}{*}{ Pair 1 } & Pre Test Session 2 & 220,6667 & 30 & 73.99596 & 13,50975 \\
\cline { 2 - 6 } & Post Test Session 2 & 302,0000 & 30 & 70,53490 & 12,87785 \\
\hline
\end{tabular}

Table 27. Result of Paired Samples Test Session 2

\begin{tabular}{|c|c|c|c|c|c|c|c|c|c|}
\hline & & \multicolumn{5}{|c|}{ Paired Differences } & \multirow{3}{*}{$\mathrm{t}$} & \multirow{3}{*}{ df } & Sig. \\
\hline & & \multirow[t]{2}{*}{ Mean } & \multirow[t]{2}{*}{ Std. Deviation } & \multirow{2}{*}{$\begin{array}{l}\text { Std. Mean } \\
\text { Error }\end{array}$} & \multicolumn{2}{|c|}{$\begin{array}{l}\text { 95\% Confidence Interval of the } \\
\text { Difference }\end{array}$} & & & \\
\hline & & & & & Lower & Upper & & & \\
\hline Pair 1 & $\begin{array}{c}\text { Pre Test } \\
\text { Session } 2 \text { - } \\
\text { Post Test } \\
\text { Session } 2\end{array}$ & -81.333333 & 86.61183 & 15.81308 & -113.67472 & -48.99194 & $-5,143$ & 29 &, 000 \\
\hline
\end{tabular}

The results of the Paired Sample T-Test for session 1 showed a significance value (2-tailed) $=0.001$. This indicates that the significance value (2-tailed) $<0.05$ so that Ho is rejected and Ha is accepted. This means that there is an average difference between the pretest and posttest session 1 learning outcomes, and this means that there is an effect of the course model and training based on the Online Course Application Service (LAO-Course) and the Learning Management System (LMS) in improving learning outcomes in session 1 .

\section{Session Effectiveness Test 2}

The results of the pretest and posttest session 2 were analyzed using the SPSS application descriptively; the following data in table 25 were obtained.

After the Paired Sample T-Test was carried out using SPSS for course learning and training session 2, the following data in table 26 were obtained.

The results of the Paired Sample T-Test for session 2 showed a significance value (2-tailed) $=0.000$. This indicates that the significance value (2-tailed) $<0.05$ so that Ho is rejected and Ha is accepted. This means that there is an average difference between the pretest and posttest session 1 learning outcomes, and this means that there is an effect of the course model and training based on the Online Course Application Service (LAO-Course) and the Learning Management System (LMS) in improving learning outcomes in session 2 .

\section{Discussion}

The implementation of the online application service-based course and training model (LAO-Course) and the Learning Management System (LMS) is packaged in the form of learning book products tested on early childhood education teachers. The results of this limited trial are in the form of an operational model for developing the computer skills of student office applications through the online application service-based course and training model (LAO-Course) and the Learning Management System (LMS). The validator's assessment of the development product which includes all the tools that have been presented is declared valid as a whole so that it is feasible to be used and developed. In other words, competency development products meet the feasibility aspect. In terms of validity, it shows that the assessment of the five validators of student competency development products through the online application service-based course and training model (LAO-Course) and Learning Management System (LMS) which includes all the tools that have been presented, can be declared valid as a whole so that it is declared worthy used. used and developed in Makassar City.[25]The validation process usually assesses various aspects of the product, including aspects of language, content, and presentation. However, some experts assess several aspects of the validation test, such as adequacy, coherence, suitability, and usability. A product can be proven valid if experts believe that product development can measure the skills specified in the measured domain.[26]

In terms of practicality, something is said to be practical if the experts state that online application service-based courses and training (LAO-Courses) and Learning Management Systems (LMS) can be used without 
revisions or minor revisions. Based on the results of the practicality assessment in general, the results show that the online application service-based course and training model (LAO-Course) and the Learning Management System (LMS) fulfil the practical aspect so that this model is feasible to use. Practical test of students' competency development through measuring the course model and training based on online application services (LAO-Course) and Learning Management System (LMS) can be done by responding to students and instructors with questionnaires. A product is declared practical if it meets two criteria, namely the instructor's assessment that the model can be applied with a few revisions and the model can be applied because it is my current learning developments, time allocation, and conditions of course and training institutions. In addition, the results of the instructor's responses obtained an average value of $63.37 \%$ of instructors said it was very good, $33.95 \%$ said it was good, and $2.68 \%$ said it was not enough. With this percentage of results, it means that the practicality response to this model can be said to be active. Therefore, instructors agree that courses and training based on online application services (LAO-Courses) and Learning Management Systems (LMS) can improve students' competencies. While the average score of students based on the results of student responses shared regarding the practicality of the online application service-based course and training model (LAO-Course) and Learning Management System (LMS) was $54.83 \%$ of students said they strongly agreed, 41.92\% agreed, 2.92 disagree and $0.33 \%$ disagree. With the percentage of results obtained, it shows that students in providing an assessment of this model can be said to be active.

Apart from being valid and practical, the online application service-based course and training model (LAO-Course) and the Learning Management System (LMS) are also effective in improving students' competency abilities. This can be seen from the results of the t-test using the SPSS application[27]which states that there is an increase in learning outcomes in the posttest score when compared to the pretest score. In line with these findings, effectiveness can be seen from three aspects, namely: (a) achieving goals by the set priorities, (b) conformity with needs, and (c) having positive aspects. effect on increasing knowledge, attitudes, and behavior.

\section{Conclusions}

This research was a type of research and development using the ADDIE procedure. The limitation in this research was the product development of courses and training starting from the analysis stage, the design preparation stage, the development stage, the implementation stage, and the evaluation stage. At the analysis stage, related preliminary studies have been carried out. Online learning was currently being held in the course and training institutions, where the data obtained is only $15 \%$ of course and training institutions that have implemented online learning. Then, 85\% provide conventional course and training services, both in terms of services and in the learning process. The drafting stage of the design produced several products starting from online application service-based course and training model (LAO-Course) and Learning Management System (LMS), A Handbook for Course and Training Institution Managers, Instructor's Manual, Student's Manual. The development stage consists of three activities to test the results of product development, namely testing the validity, practicality, and effectiveness. The implementation stage is to conduct course trials and training based on online application services (LAO-Course) and Learning Management System (LMS) limited to one group of early childhood education teachers spread across several districts and cities. Based on the results of research data analysis, each stage of the development of this model shows that the product being developed is valid according to the expert. The results of this validity test were carried out by 5 experts consisting of 2 material experts, 2 media experts, and 1 linguist. The two practical tests of the online application service-based course and training model (LAO-Course) and the Learning Management System (LMS) were carried out on 7 instructors as respondents and 30 early childhood education teachers. The results of this practitioner's assessment indicate that the online application service-based course and training model and the Learning Management System (LMS) are considered practical, starting from the use of online application services (LAO-Course), the use of google classroom Learning Management System (LMS), and several indicators in instrument model practicality. The evaluation stage is to test the effectiveness of the model through the course and training activities by testing one type of course program, namely a computer course and learning for 60 hours online which is divided into 2 sessions. Before being given learning, each session was given a pretest instrument to measure students' initial abilities. After that, the instructor is given learning. At the end of each session, a post-test instrument is given to measure whether there is a change in the value of the students. This test is conducted to determine whether there is an effect of the model on improving student learning outcomes. The results of the Paired Sample T-Test for session 1 and session 2 showed a significance value (2-tailed) $=0.001$ and 0.000 . This indicates that the significance value (2-tailed) $<0.05$ so that Ho is rejected and Ha is accepted. This means that there is an average difference between the pretest and posttest learning outcomes session 1 and session 2, this means that there is an influence on the course model and based training. Online application service (LAO-Course) and Learning Management System 
(LMS) in improving computer learning outcomes for Early Childhood Education teachers.

The finish of this investigation is Right now with the presence of different web-based learning applications that can be utilized to learn at home. Beginning from paying internet software apps to open learning applications, these learning applications were on a basic level truly adept at supporting distance learning with an online framework, particularly with the present status of the Covid19 pandemic. Albeit different highlights and benefits of different applications have shown up right now, on normal these applications just help the understudy learning measure without giving space to instructors to cooperate and team up in them. Albeit the online-based learning application additionally has instructional exercises or even incorporates direct coaches, it actually can't supplant the instructor's part in the eye to eye educating and learning measure.

\section{REFERENCES}

[1] Ministry of Education and Culture of the Republic of Indonesia, "Law Number 20 of 2003 concerning the national education system." 2003.

[2] "The Development of Information and Communication Technology in the Education Sector in Indonesia Kompasiana.com." Accessed: Mar 28, 2021. [Online]. Available at: https://www.kompasiana.com/abyzarchelsea00 74/5d9c9d0c097f366b992563d2/perkembangan-teknologi-i nformasi-dan-komkom-kom-pada-bidang-pendidikan-di-ind onesia.

[3] E. Hero, "LMS is a New Innovation in the World of Education," Widya Edu's blog, Sep 09, 2020. https://widyaedu.com/blog/lms-adalah-inovasi-baru-dalamdunia-pend Pendidikan/ (accessed Feb 01, 2021).

[4] ardraviz, "The Effect of Unemployment on the State Economy. Understanding Explanation For example, "ardra.biz.

https://ardra.biz/ekonomi/ekonomi-makro/pentuk-peng unemployment-terhadap-perekonomi-negara/ (accessed Jul 14, 2020).

[5] Y. Riyanto, New Paradigm of Learning, 3rd printing. Kencana Prenada Media Group, 2012.

[6] NA Alias and AM Zainuddin, "Innovation for Better Teaching and Learning: Adopting the Learning Management System," p. 14, 2005.

[7] "10 advantages and disadvantages of Google Classroom that must be known," Wayah-e. https://wayah-e.blogspot.com/20 20/04/10-kelelu-dan-kekurang-google-classroom-yang-waji b-diketknown.html (accessed Feb 01, 2021).

[8] "GOVERNMENT REGULATION OF THE REPUBLIC OF INDONESIA NUMBER 19 YEAR 2005 CONCERNING NATIONAL STANDARDS OF EDUCATION." .

[9] Ministry of Education and Culture, Vocational Education Revitalization. 2016.
[10] "Can Online Learning Disrupt Formal Education? | Marketeers - Business Magazine \& Online Marketing Marketeers.com." https://marketeers.com/dapatkah/ (accessed Jan 25, 2020).

[11] Putu Sudira, Vocational and Vocational Education Philosophy and Theory.pdf, Printing 1. UNY Press, 2012.

[12] S. Lonn and SD Teasley, "Saving time or innovating practice: Investigating perceptions and uses of Learning Management Systems," Comput. Educ., vol. 53, no. 3, p. 686-694, Nov 2009, doi: 10.1016 / j.compedu.2009.04.008.

[13] N. Cavus and MS Alhih, "Learning Management Systems Use in Science Education," Procedia - Soc. Behav. Sci., vol. 143, p. 517-520, Aug 2014, doi: 10.1016 / j.sbspro.2014.07.429.

[14]GC Oproiu, "A Study about Using E-learning Platform (Moodle) in University Teaching Process," Procedia - Soc. Behav. Sci., vol. 180, p. 426-432, May 2015, doi: 10.1016 / j.sbspro.2015.02.140.

[15] G. Mozhaeva, A. Feshchenko, and I. Kulikov, "E-learning in the Evaluation of Students and Teachers: LMS or Social Networks ?," Procedia - Soc. Behav. Sci., vol. 152, p. 127130, Oct 2014, doi: 10.1016 / j.sbspro.2014.09.168.

[16]A. net-AJN Network, "The Relationship between Digital Business Actors, Education, Research in the Industrial Revolution Era 4.0.," AJNN.net. https://www.ajnn.net/news/hubung-antara-pelaku-bisnis-dig ital-pend Pendidikan-pen Research-pada-era-revolusi-indust ri-4-0/index.html (accessed Jan 31, 2020).

[17] JM Weinhardt and T. Sitzmann, "Revolutionizing training and education? Three questions regarding massive open online courses (MOOCs), "Hum. Resour. Manag. Rev., vol. 29, no. 2, p. 218-225, Jun 2019, doi: 10.1016 / j.hrmr.2018.06.004.

[18] N. Kidi, B. Kanigoro, AG Salman, YL Prasetio, I. Lokaadinugroho, and AA Sukmandhani, "Android Based Indonesian Information Culture Education Game," Procedia Comput. Sci., vol. 116, p. 99-106, 2017, doi: 10.1016 / j.procs.2017.10.015.

[19] T. Sitzmann and JM Weinhardt, "Advancing training for the 21st century," Hum. Resour. Manag. Rev., vol. 29, no. 2, p. 137-139, Jun 2019, doi: 10.1016 / j.hrmr.2018.07.005.

[20] RM Branch, Instructional Design: The ADDIE Approach. Boston, MA: Springer US, 2009.

[21] Sugiyono, "Educational Research Methods. Quantitative, Qualitative, and R \& D Approaches, ”CV. ALFABETA, Bandung, 2013, p. 458.

[22] Sugiyono, "Research and Development Methods for the fields of Education, Management, Social, Engineering," vol. 3rd printing, CV. ALFABETA, Bandung, 2017, p. 712.

[23] "Benjamin S. Bloom - Taxonomy of Educational Objectives, Handbook 1_ Cognitive Domain-Addison Wesley Publishing Company (1956) .pdf." .

[24] Arikunto, S, Research Procedure A Practical Approach. Jakarta: Rineka Karya, 2008.

[25] Walter R.Borg, Meredith D. Gall, Joyce P. Gall, Educational Research An Introduction, 7th Edition. Pearson Education 
Inc. Boston USA, 2003.

[26]"Van Den Aker Et - Educational Design Research_ The Design, Development and Evaluation of Programs, Processes and Products (2006) .pdf." .

[27] Singgih Santoso, Complete Guide to SPSS 26. PT. Elex Media Komputindo. 